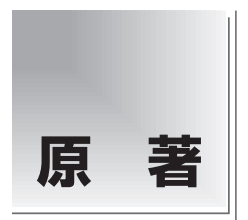

論文受付

2020 年 1 月 30 日

論文受理

2020 年 9 月 22 日

Code No. 251

\section{樑層学習とワークステーションを用いた 小児生体肝移植後の体積測定}

\author{
江崎 徹 ${ }^{1}$ 古川理恵子 ${ }^{2}$
}

${ }^{1}$ 自治医科大学附属病院中央放射線部

${ }^{2}$ 自治医科大学とちぎ子ども医療センター小児画像診断部

\section{緒 言}

国内における生体肝移植は 1989 年から開始され, 9000 例以上施行されている。レシピエントは 0-9 歳 が最多で，原疾患は胆道閉鎖症が主である ${ }^{1)}$ 。胆道閉 鎖症は, 出生 10000-12000 人に一人の頻度で発生し, 一般的には葛西手術が行われるが，術後に胆汁排泄が 得られず黄疸が増強する症例, 軽減した黄疸が再び増 強する症例，あるいは黄疸が消失してもコントロール のつかない食道静脈瘤や上行性胆管炎などの重症続発 症を併発した症例は肝移植の適応となり得る2). 小児 生体肝移植は成人と比較して予後が良好であるが3), 現状では移植後長期にわたり合併症の発症に留意する 必要がある4).
移植される肝臟(グラフト肝)の体積は, 体表面積か ら計算された標準肝体積 ${ }^{5)}$ の $40 \%$ 程度であるが, 移植 後 2 力月まで急速に再生し標準肝体積を超え, 4 力月 後には $90 \%$ に減少する ${ }^{6)}$. 脾臟体積は肝移植後に縮小 するが ${ }^{7)}$, 生体肝移植の合併症である肝静脈の閉塞も しくは狭窄等による循環不全, 感染症や移植片対宿主 病による肝機能悪化が脾臟腫大の要因となる ${ }^{8)}$. グラ フト肝, 脾臓体積は肝再生, 合併症の有無を判断する 因子であり，体積測定は臨床上重要である.

Computed tomography (CT) 画像を使用した体積測 定は, 誤差が少なく ${ }^{9)}$ 臨床で多く用いられる。しか し，体積測定のために領域抽出が必要である。CT 画 像における領域抽出の研究が行われ, 抽出精度が向上

\title{
Volume Measurements of Post-transplanted Liver of Pediatric Recipients Using Workstations and Deep Learning
}

Toru Esaki ${ }^{1 *}$ and Rieko Furukawa ${ }^{2}$

${ }^{1}$ Department of Radiologic Technology, Jichi Medical University Hospital

${ }^{2}$ Department of Pediatric Medical Imaging, Jichi Children's Medical Center Tochigi

Received January 30, 2020: Revision accepted September 22, 2020

Code No. 251

\section{Summary}

Purpose: The purpose of this study was to propose a method for segmentation and volume measurement of graft liver and spleen of pediatric transplant recipients on digital imaging and communications in medicine (DICOM) -format images using U-Net and three-dimensional (3-D) workstations (3DWS). Method: For segmentation accuracy assessments, Dice coefficients were calculated for the graft liver and spleen. After verifying that the created DICOM-format images could be imported using the existing 3DWS, accuracy rates between the ground truth and segmentation images were calculated via mask processing. Result: As per the verification results, Dice coefficients for the test data were as follows: graft liver, 0.758 and spleen, 0.577 . All created DICOM-format images were importable using the 3DWS, with accuracy rates of $87.10 \pm 4.70 \%$ and $80.27 \pm 11.29 \%$ for the graft liver and spleen, respectively. Conclusion: The U-Net could be used for graft liver and spleen segmentations, and volume measurement using 3DWS was simplified by this method.

Key words: deep convolutional neural network, volume measurements, living donor liver transplantation, computed tomography

\footnotetext{
*Corresponding author
} 
した結果, 臨床で使用されている three-dimensional workstation(3DWS)でも自動抽出が可能になった ${ }^{10)}$.

しかし, 小児生体肝移植では肝臓の左葉を移植するこ とが多く，正常解剖と異なるため，既存の 3DWS では 自動抽出困難であることに加えて, 脾臟を自動抽出可 能な3DWS は少ない．現状では手作業による抽出が 必要であり, 多大な時間と労力を要するため, 自動抽 出する手法が望まれる。

近年, 自動抽出の手法として, 深層学習 (deep learning)の有用性が報告されている. 従来の抽出手 法は, 臓器の形状, 血管, CT 值などの特徽を, 抽出ア ルゴリズムに反映させるため，プログラム作成には豊 富な経験と時間が必要であった ${ }^{11}$ 。深層学習の中でも convolutional neural network (CNN) は，画像をネット ワークに入力するだけで特徵量を抽出する重みを学習 するため, 従来の手法と比較して簡便かつ高精度に抽 出可能である ${ }^{12 \sim 15)}$. 医用画像に㧍ける CNNを用いた 領域抽出では, U-Net ${ }^{16)}$ と呼ばれるネットワークの有 用性が報告され, 肝臟・脾臟の領域抽出にも利用され ている17.18).

しかし，小児生体肝移植レシピエントを対象とした U-Net による抽出精度は評価されていない。また，U一 Net の抽出精度は Dice 係数 ${ }^{19)}$ で評価されているが,

Dice 係数は類似度を表し, 抽出領域の体積は評価困難 である。

抽出領域の体積は, digital imaging and communications in medicine(DICOM) header から pixel サイズ, スライス厚を取得し, 抽出領域の pixel 数を乗じて評 価可能である。しかし，算出された数值のみを picture archiving and communication systems(PACS)に 送信するのは臨床上現実的ではない，日常の臨床では 3DWS で体積測定後，測定領域確認のために，領域抽 出された画像と CT 画像をフュージョン ${ }^{20)}$ すること が想定される，臨床と同一の環境で体積を評価するた めには，3DWSによる体積測定が必要と考える。

3DWS は正確なフュージョンのために, DICOM headerの位置情報を利用する ${ }^{21)}$ ，更に患者情報を利 用することで患者取り違え防止につながる. U-Netの 学習に非 DICOM 形式のデータセットを使用してい る文献が散見されるが22 24)，DICOM 形式を portable network graphics (PNG), bitmap 形式へ変換する際 の, window width(WW), window level(WL)設定に より, 造影コントラストがCT 画像と異なることで, 特徵量を抽出する重みに影響を与えると予想される. したがって，医療安全の観点㧍よび抽出精度を高める ためにはデータセットと抽出結果は DICOM 形式で

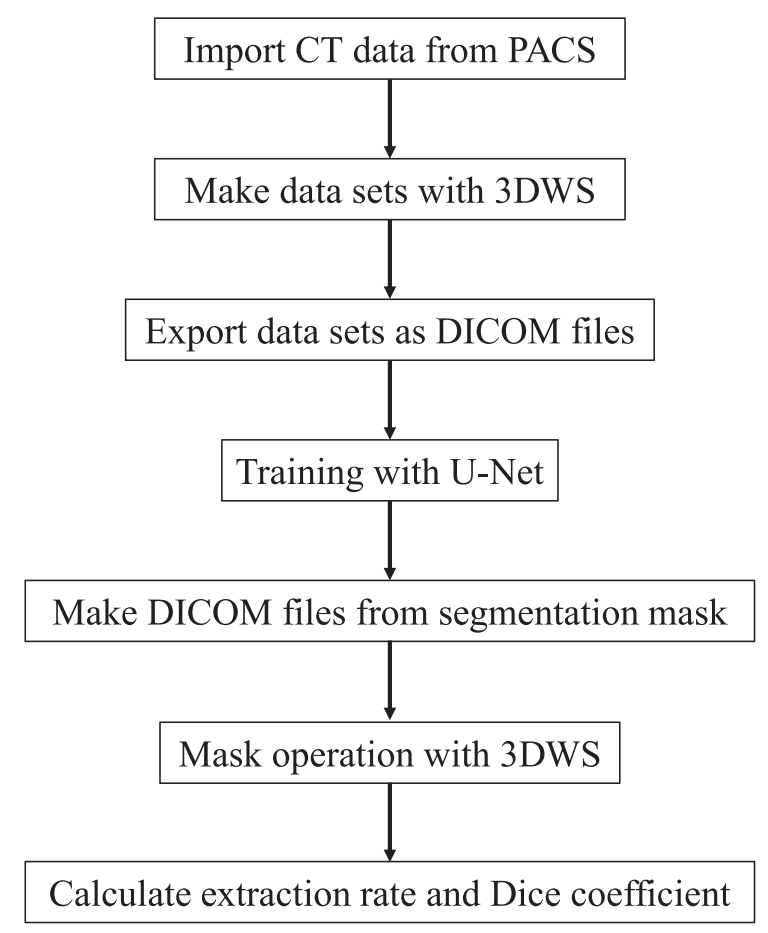

Fig. 1 Procedure of the proposed method.

あることが求められる.

本研究の目的は, U-Netによる小児生体肝移植レシ ピエントのグラフト肝, 脾臓抽出精度を評価するとと もに, 抽出結果から DICOM ファイルを作成し, 3DWS にて体積を測定する手法を提案することである.

\section{1. 方 法}

\section{1-1 本研究の対象者}

本研究のワークフローを示す (Fig. 1)。対象者は, 当院で 2018 年 6 月〜 2019 年 1 月までに小児肝臟移植 後の経過観察を目的として, 造影 CT が撮影された 120 例とした. U-Netの学習には訓練用, 評価用とし て，2018 年 6〜11月までに撮影された 100 例，U-Net により作成された抽出モデルのテスト用として 2018 年 12 月〜 2019 年 1 月までに撮影された 20 例を対象とし た。年齢は 0-32 歳, 平均年齢は 11.8 歳, 中央值は 12.0 歳であり, 同一被検者は含まれていない. 本研究 は当院倫理委員会の承認を得ている.

\section{1-2 撮像条件}

\section{1-2-1 CT 撮影条件, 造影剂注入条件}

CT 装置は SOMATOM Definition Flash, SOMATOM Definition AS+(Siemens Healthineers, Erlangen, Germany)を使用した。管電圧は Care $\mathrm{kV}$ (Level-6)にて 自動で選択された $80 \mathrm{kV}$ または $100 \mathrm{kV}$, 管電流は Quality Ref.mAsを $140 \mathrm{mAs}$ に設定した。各年齢に 
Table Average CTDIvol at each age

\begin{tabular}{ccccc}
\hline \hline Age [year] & 0 & $1-5$ & $6-10$ & $10-$ \\
\hline CTDIvol [mGy] \pm SD & $1.56 \pm 0.12$ & $2.84 \pm 0.50$ & $4.49 \pm 1.57$ & $8.51 \pm 2.70$ \\
\hline
\end{tabular}

CTDIvol indicates a value of $32 \mathrm{~cm}$ in diameter.

おける CTDIvol の平均值は最大でも診断参考レベ ル25)の半分程度であった(Table)。被検者の年齢が乳 児から成人まで幅広いため, モーションアーチファク 卜を考慮して, 回転速度 0.28-0.5 s/rot, pitch factor 0.6-2.5 の範囲で適宜変更した。造影剤はイオヘイキ ソール(オムニパーク 300 ; GEヘルスケアファーマ, 東京) $600 \mathrm{mgI} / \mathrm{kg}$ を 50 秒注入し, 造影剤注入開始か ら 80 秒後に撮影した。

\section{1-2-2 逐次近似応用再構成}

逐次近似応用再構成である SAFIRE は, 画像ノイ ズを低減することで被ばく低減を可能にする ${ }^{26)}$. SAFIRE の画像ノイズ低減強度である strength は 5 段階から選択可能であり, strength 1 のノイズ低減効 果は最も低く, strength 5 は最も高いノイズ低減効果 が得られる ${ }^{27)}$. 高い strength を用いた再構成画像は, filtered back projection (FBP) と比較してテクスチヤ が異なるため ${ }^{28)}$, 腹部領域における strength は 2 また は, 3 が推奨されている29).

当院でも小児肝臟移植後の CT 検査において, 被ば く低減効果と画質を放射線科医と協議の結果, strength 2 を採用した。 体積測定のために, 診断用と 異なる再構成関数, strengthによる再構成は, 検査の ワークフローが煩雑になるため, 本研究では臨床と同 一の再構成関数 I36f (strength 2), スライス厚 $3 \mathrm{~mm}$ を使用した。

\section{1-3 データセット作成}

臨床における体積測定は, 診療放射線技師が手作業 で領域抽出を行う。手作業で抽出した領域と CT 画像 がフュージョンされた画像を体積測定結果とともに PACS へ送信する。フュージョン画像は放射線科医が 読影時に抽出領域の整合性確認するのに使用され，体 積測定結果は移植外科医が患者のフォローアップ項目 として使用する。本研究では, PACSに送信された フュージョン画像を参照して, 経験年数 13 年の診療 放射線技師 1 名がSYNAPSE VINCENT V5.3.0001(富 士フイルムメディカル, 東京)を用いてデータセット を作成した。

CT 画像を PACS からインポートを行い, マスク編 集機能を使用してグラフト肝に region of interest （ROI）を手動で設定後, 動脈, 門脈, 静脈は閾值を設
定してマスクから除外した。設定したマスクを反転 後, 非マスク領域の voxel 值を 1024 に設定しマスク 適用画像保存を行った。保存した画像を 3D ビューア で表示し，対象領域の膨張サイズを 0 に設定後, volume rendering (VR) 画像上で voxel 值が 1024 のグラ フト肝を抽出した。非マスク領域の voxel 值を-1024 に設定したマスク適用画像をグラフト肝の教師画像と して体積測定を行い，教師画像体積とした。同様の方 法で脾臟の教師画像作成を行い, CT 画像と教師画像 を DICOM 出力することでデータセットを作成した. グラフト肝のデータセットを教師画像体積昇順に並 べ，5例㧍きに評価用として選択し，訓練用 80 例，評 価用 20 例をとした，なお，訓練用，評価用，テスト用 の被検者は, グラフト肝用と脾臓用で同一とした。 CT 画像の枚数は, 訓練用 4420 枚, 評価用 1129 枚, テ スト用 1293 枚であり, 教師画像も同一枚数である.

\section{1-4 開発環境およびU-Net による抽出モデル作成}

ハードウェアは CPU Core i5 9600k (Intel Corporation, Santa Clara, CA, USA), メモリ 32GB, GPU GeForce GTX1070 8GB (NVIDIA Corporation, Santa Clara, CA, USA), ソフトゥェアは Windows10 Proに Anaconda Navigator をインストール後 Python 3.6 の仮想環境を 構築L, Jupyter Notebook, NumPy, Pydicom, TensorFlow GPU をバックエンドとした Kerasを使用した。

CT 画像の DICOM tag (7FE0, 0010)に格納されてい る pixel data をPydicom で NumPy 配列として抽出 L, float32 の四次元配列 [画像枚数, 解像度, 解像度, チャンネル数]を作成した ${ }^{30}$. 本研究では解像度を $512 \times 512$ pixels, チャンネル数を 1 チャンネルに設定 した．教師画像も同一手順で DICOM ファイルから， 四次元の NumPy 配列を作成した，作成された配列の 最大 pixel 值で正規化を行い U-Net (Fig. 2)に入力した.

U-Net の構造は左右対称のU 字型であり, 左側に encoder，右側に decoder が含まれる ${ }^{31}$. 本研究で使 用したU-Net の encoder 部は，4段階で構成され，全 段階で畳み込み層とバッチ正規化層が 2 回繰り返され る. 畳み込みのフィル夕数を $64,128,256,512$ とし て，1段階ごとに増加させた。畳み込み層では, 畳み 込み前の画像をゼロパディング後, kernel size が $3 \times 3$ のフィルタを strides 1 で畳み込みを行い, 活性化関数 


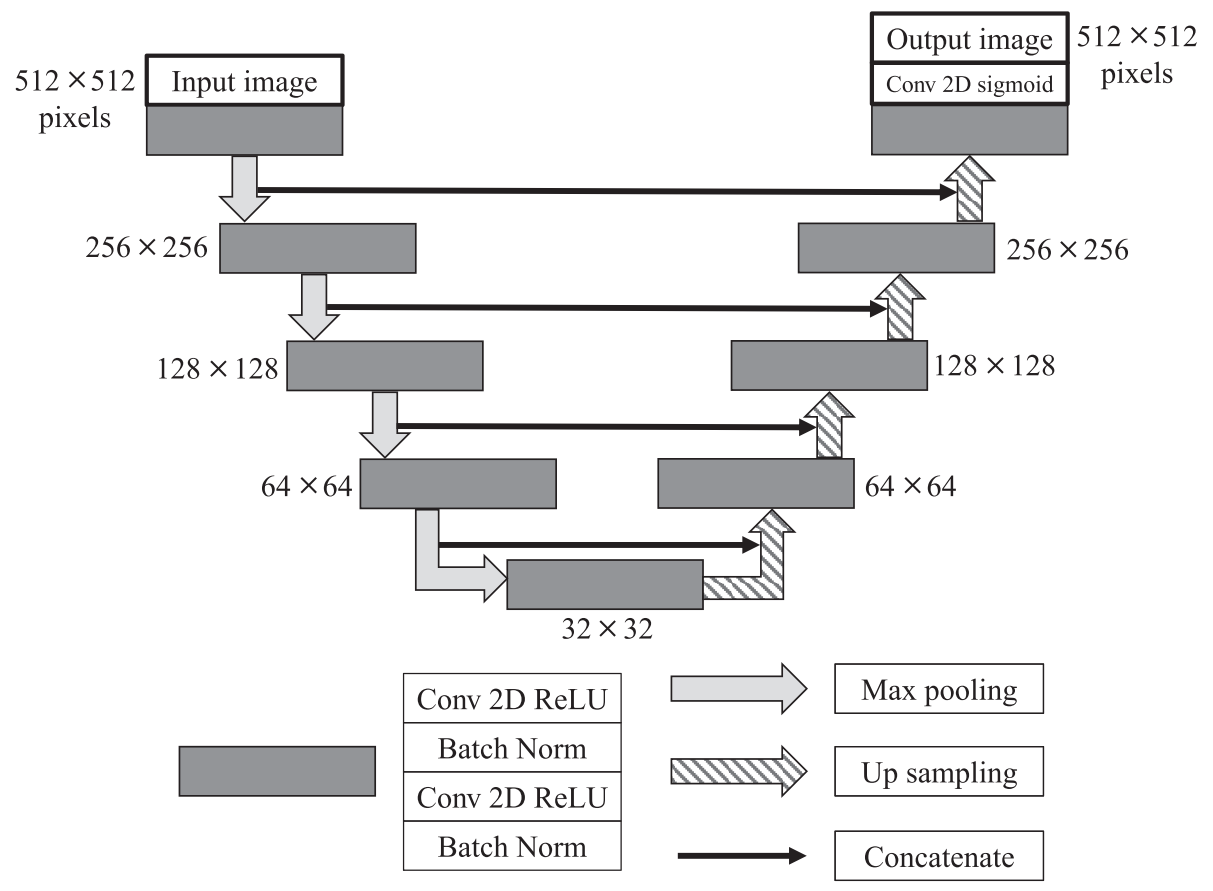

Fig. 2 U-Net model architecture.

Conv 2D indicates the two-dimensional convolutional layer, ReLU represents the activation function used, and Batch Norm denotes the batch normalization function. The convolutional and batch normalization layers are repeated in the colored rectangles.

は ReLU ${ }^{32)}$ を用いた。バッチ正規化層では Kerasの batch normalization 関数を用いた。助み込みとバッ チ正規化を繰り返した後に, kernel size が $2 \times 2$ のフィ ルタを strides 2 で max poolingを行った。

U-Net の最下段では，畳み込みとバッチ正規化を繰 り返した後に max pooling は行わず, 出力を decoder 部へ入力した. decoder 部では Keras の up sanmpling2D でアップサンプリングを行い, 同一解像度の encoder 部からの出力を連結後, 畳み込みとバッチ正 規化を繰り返した。最後の畳み达み層では, kernel size が $1 \times 1$ のフィルタ 1 個を strides 1 として, sigmoid 関数の出力值を解像度 $512 \times 512$ pixels で出力した.

U-Netのパラメータに利用した評価関数は, 教師画 像およびU-Netから自動抽出された画像 (自動抽出画 像)の Dice 係数 (1) とした.

$\operatorname{Dice}_{(\mathrm{X}, \mathrm{Y})}=\frac{2 \times|\mathrm{X} \cap \mathrm{Y}|}{|\mathrm{X}|+|\mathrm{Y}|+1}$

ここで X は教師ラベルの画素数, Y は自動抽出ラ ベルの画素数を示す.

データセットには, グラフト肝，または脾蔵より広 範囲の画像が存在する。グラフト肝または脾臓が含ま れない画像は教師ラベルになる画素が存在しないた め, 教師ラベルの画素数 X は 0 pixel になる. 教師ラ ベルが存在しない画像から，学習の過程でU-Netによ
る領域抽出を行い, 自動抽出ラベルが存在しない場合 も自動抽出ラベルの画素数 Y は 0 pixel になる.この とき，分子が 0 で除算されると評価関数の值は算出さ れず，学習が困難になる。本研究では評価関数の分子 が 0 で除算されるのを防止するため分母に 1 を加算し た

損失関数は，体積測定を目的とする CNN において binary crossentropy が推奨されている ${ }^{34)}$. そこで本研 究は, 損失関数を(2)式で定義した ${ }^{35)}$.

損失関数 $=1-$ Dice 係数 + binary crossentropy

なお, binary crossentropy は Kerasに実装されて いる損失関数を用いた。

Optimizer, learning rate, batch size は, 損失関数 の最小值および，最小值が得られる時間に影響す る ${ }^{36,37)}$. そのため, これらのパラメータは, U-Netの 領域抽出精度や学習時間を決定する因子であると考え られる。本研究において, optimizer はU-Netで多く 利用されている ${ }^{38 \sim 40)}$ Adam $^{41)}$, learning rate は Keras で初期值として設定されている 0.001, batch size は GPUメモリの制限により 2 とした。 Epochは 100 epochs に設定したが, 損失が最小のモデルを抽出モ デルとして採用した。 なお，抽出モデルの精度評価に は, hold-out 法 ${ }^{42)}$ を用いた。 


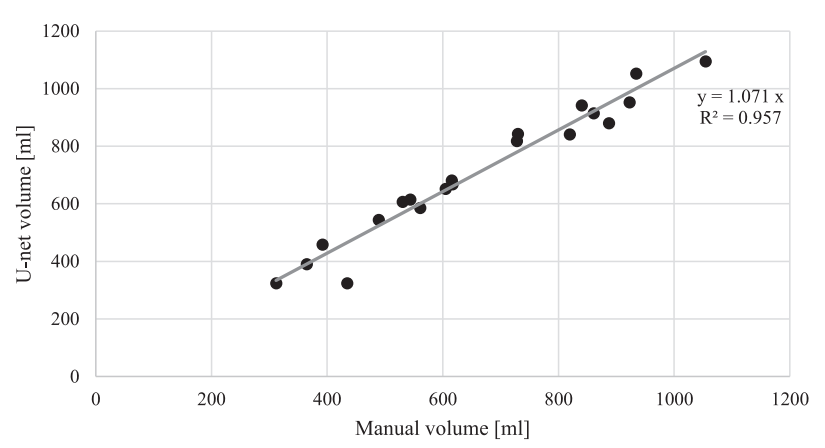

Fig. 3 Relationship between manual volume and U-Net volume in the graft liver.

\section{1-5 自動抽出および抽出画像の DICOM ファイル作成}

モデル作成時に使用していない CT 画像 20 例を, 四次元 NumPy 配列に変換後, U-Netにて作成された 抽出モデルに入力し, グラフト肝, 脾臓の自動抽出を 行った．抽出モデルから出力される配列は四次元の NumPy 配列であるため, 画像枚数要素ごとに[解像 度, 解像度]の二次元配列に変換した。二次元配列の 要素に 1024 を乗じて, int16に変換することで pixel dataを作成し, 抽出モデルに入力したCT 画像と同一 の DICOM header を pixel dataに付加した. 付加し た DICOM header の DICOM tag $(0008,0018)$ ，および (0020, 000E) に格納されている SOP instance UID, series instance UID を重複しない值に変更すること で, 出力された配列から DICOM ファイルを作成した。

\section{1-6 Dice 係数および体積評価}

教師画像と抽出モデルにより自動抽出された画像 (自動抽出画像)の Dice 係数の平均值を求めた. Dice 係数は教師画像と自動抽出画像の体積比較が困難であ るため, 3DWS で測定したマスク体積を用いて, 抽出 体積の正確度を定義した。

作成された自動抽出画像を 3DWS にインポート後, 教師画像とともにマルチ 3D で表示した。䐍張サイズ を 0 に設定後, VR 画像上で voxel 值が 0 以上の物体 抽出を行い, 自動抽出画像マスクおよび教師画像マス クを作成した，作成したマスク領域の体積を 3DWS の体積測定機能を用いて測定し, 直線回帰式, 相関係 数を求めた。自動抽出画像マスクから教師画像マスク 減算後の体積を過抽出体積, 教師画像マスクから自動 抽出画像マスク減算後の体積を未抽出体積として, 正 確度を次式で求め平均值を算出した。正確度は過抽 出，未抽出が低いときに高值を示す．

過抽出 $=$ 過抽出体積 / 教師画像体積 $\times 100 \quad \cdots(3)$

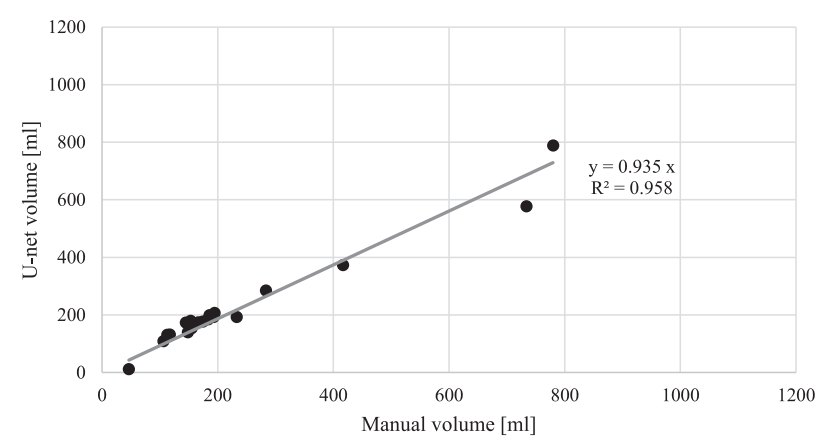

Fig. 4 Relationship between manual measurement volume and U-Net volume in the spleen.

未抽出 $=$ 未抽出体積 / 教師画像体積 $\times 100 \quad$.. (4)

正確度 $=100$ 一過抽出一未抽出

3DWS による体積測定值の精度検証を目的として， 下記の (6) 式にてグラフト肝の教師画像の体積を算出 した。

Manual calculation volume $=$ pixel size $\times$ pixel size $\times$ thickness $\times$ pixel count $\times 10^{-3}$

ここで, pixel size $(\mathrm{mm})$, thickness $(\mathrm{mm})$ は, DICOM $\operatorname{tag}(0028,0030)$ および $(0018,0050)$ の pixel spacing, slice thickness から抽出した。また, pixel count (pixels)は DICOM tag (7FE0, 0010)の pixel dataを Pydicom にて NumPy 配列に変換後, 配列の要素が 0 以上 の要素数とした.

また，3DWS で測定した体積と(6)式から算出され た体積の直線回帰式を求めた。

\section{2. 結 果}

U-Net によるグラフト肝および脾臓の学習時間は両 者ともに 36 時間要した。学習の結果, 採用したモデ ルの epoch 数は, グラフト肝が $84 \mathrm{epoch}$, 脾臟が 87epochであった。

被検者 20 名分の CT 画像からグラフト肝, 脾臓を 作成したモデルで抽出し DICOM ファイル作成完了 までに 6 分要した。テスト用の Dice 係数は，グラフ 卜肝が $0.758 \pm 0.367$, 脾臓が $0.577 \pm 0.441$ でありグラフ ト肝が脾臓と比較して高值を示した。

作成された自動抽出画像と 3DWS に保存されてい る被検者ごとの CT 画像, 教師画像はすべて同一検査 として認識され体積測定が可能であった。

教師画像体積と自動抽出画像体積の関係を示す (Fig. 3, 4). グラフト肝における自動抽出画像体積は, 教師画像体積の 1.071 倍であり, 相関係数は 0.957 で 


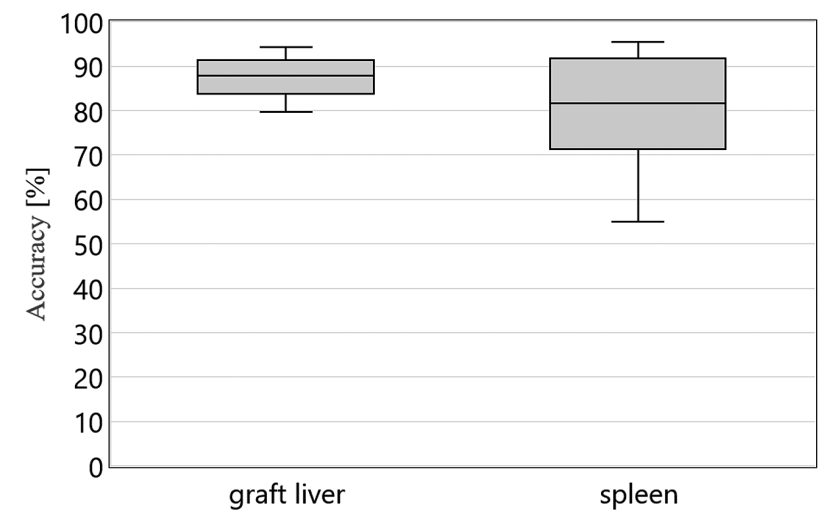

Fig. 5 Accuracy of the graft liver and spleen by U-Net.

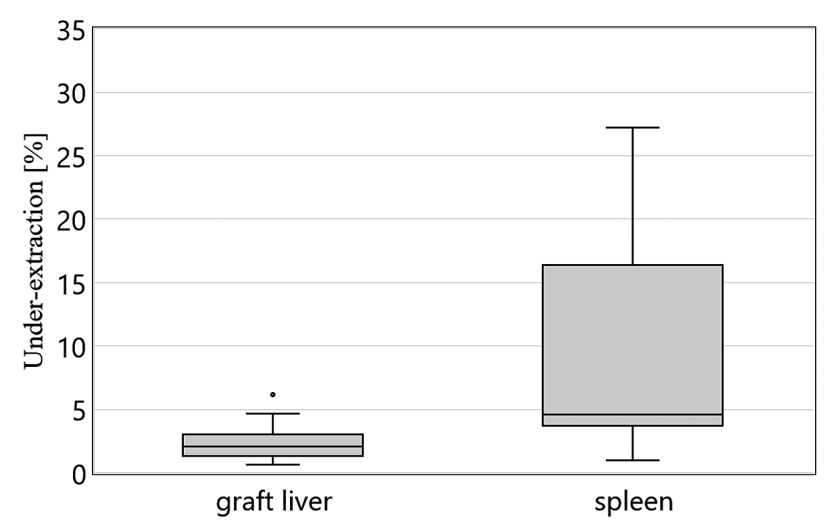

Fig. 6 Under-extraction of the graft liver and spleen by U-Net. Under-extraction of the spleen increased as compared to that of the graft liver. The difference between maximum and minimum values of the spleen was larger than that of the graft liver.

あった，脾臓における自動抽出画像体積は, 教師画像 体積の 0.935 倍であり，相関係数は 0.958 が得られた。 グラフト肝, 脾臓ともに自動抽出画像体積と教師画像 体積は正の強い相関が認められた。

正確度, 未抽出, 過抽出を示す (Fig. 5-7). 正確度 は，グラフト肝が $87.10 \pm 4.70 \% ，$ 脾蔵が $80.27 \pm 11.29 \%$ であり Dice 係数と同様にグラフト肝が脾臓と比較し て高值を示した。未抽出は, グラフト肝が $2.26 \pm$ $1.34 \%$, 脾臓が $12.27 \pm 16.87 \%$ ，過抽出はグラフト肝が $10.65 \pm 4.54 \%$ ，脾臓が 10.44 7 7.80\%であった。

3DWS で測定した体積と教師画像の DICOM header を用いて算出した体積の関係を示す (Fig. 8).3DWS で測定した体積は，教師画像の DICOM header を用 いて算出した体積の 0.9992 倍であった。相関係数は 0.9999 が得られ，正の強い相関が認められた。

\section{3. 考 察}

小児肝臓移植後レシピエントのグラフト肝および脾

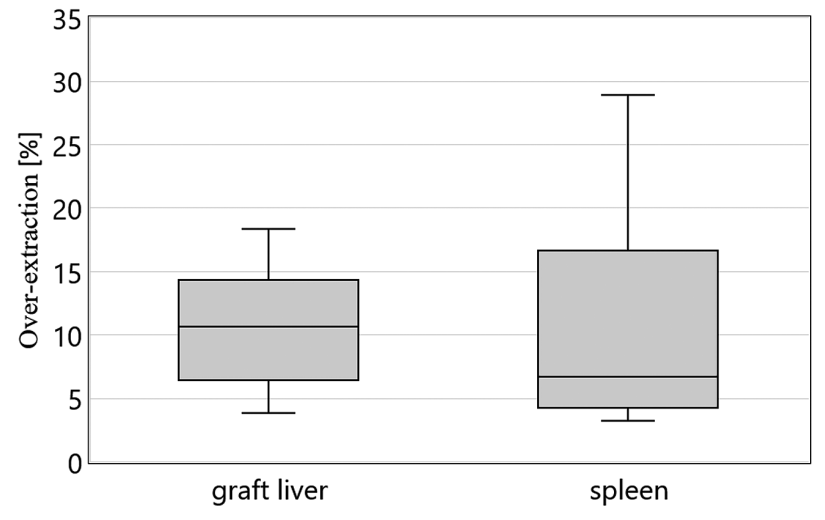

Fig. 7 Over-extraction rate of the graft liver and spleen by UNet. Over-extraction of the spleen declined as compared to that of the graft liver.

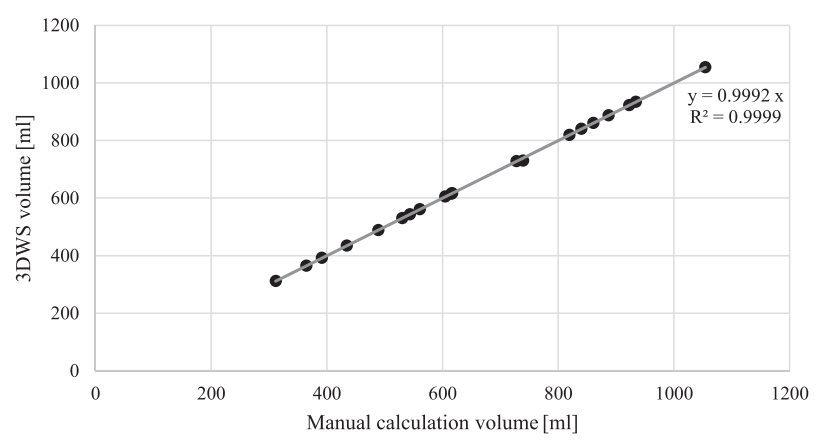

Fig. 8 Relationship between manual calculation volume and 3DWS volume.

臓の体積測定は, グラフト肝再生, 合併症の有無を判 断する因子であり, 臨床上重要である。グラフト肝, 脾臓の体積測定は, 既存の 3DWS では自動抽出困難 であるため，手作業による抽出が余儀なくされる。手 作業による領域抽出は多大な労力と時間を要するた め, 正確な自動抽出が求められる。 そこで本研究で は, グラフト肝および脾臓の自動抽出モデル作成を U-Netにて行い, 抽出画像をDICOM ファイルに変換 後, Dice 係数算出, 3DWSにて体積測定を行った。 そ の結果, 学習に使用していないテスト用画像の Dice 係数は, CNNを用いた成人における臓器抽出のDice 係数 ${ }^{43}$, 44) と比較して低下したが, 手動測定体積と自動 抽出体積は強い相関が認められた。正確度は, グラフ 卜肝が $87.10 \pm 4.70 \%$ ，脾藏が 80.27士11.29\%であった。 また, Fig. 9 に3DWS と U-Netの抽出精度の比較を示 す. All mask image の VR image は全領域のマスクを 反映している。しかし, CT image に overlay は表示 していない. 3DWS は脾蔵をセグメンテーションす るアプリケーションは実装されていない. VRの白色 は骨, 石灰化を示し, えんじ色はグラフト肝, 脾蔵, 
腸管を示し, ピンク色は心臓, 腎臓を示す。黄色の矢 印は誤って抽出された心臟を示す。青色の矢印は誤っ て抽出された腸管を示す。これらの結果から, U-Net は3DWS と比較してグラフト肝も脾臓も正確に抽出 できたと考える。

更に，データセット作成では，手作業による領域抽 出に, 被検者 1 人あたり 30 分程度要したが, U-Netで は被検者 1 人あたり 20 秒程度で自動抽出可能である. したがって, 提案手法により, 3DWS では抽出困難で ある小児肝臟移植後レシピエントのグラフト肝および 脾臟抽出の時間短縮, 負担軽減が可能になると考える.

グラフト肝と脾藏は同一枚数のデータセットを使用 しているため, 各々の臓器に対して広範囲の画像が存 在する。これによりマスク領域が存在しない画像の Dice 係数は 0 に近い值が算出され, Dice 係数が低下 したと考える。

手動測定体積と自動抽出体積は強い相関が認められ たが，自動抽出体積と手動測定体積が同一の被検者は わずかであった，手動測定体積と同一の体積が得られ なかった原因として, 教師画像と比較して, 過大また は過少に抽出した体積が存在すると考えられる。しか し, U-Netの抽出精度に用いられている Dice 係数は, 体積評価が困難である。本研究は3DWS のマスク演 算とマスク体積測定機能を用いて体積測定した，測定 した体積から算出した過抽出, 未抽出は, 教師画像マ スク体積で正規化されているため, 被検者間のマスク 体積に依存することなく，体積評価可能になった．

また, 本研究で定義した正確度は, 過抽出と未抽出 の和を 100 から減算することで, 過抽出, 未抽出が少 ない被検者で高值を示し, 過抽出, 未抽出が多い被検 者では低值を示す，正確度は抽出体積の相対的な評価 が可能であり, 絶対值としての評価は困難である。し かし, U-Netによって抽出された領域の体積評価を臨 床と同一の環境で行った報告は少ない. 3DWSの体 積は DICOM header を用いて算出した体積と強い相 関が認められた。 3DWSの体積は, CT 画像の pixel サイズ，スライス厚，マスク領域の pixel 数が反映さ れ，高い測定精度を有する，そのため，3DWSによる 体積測定扮よび正確度算出により, Dice 係数では困難 であった体積評価が臨床と同一環境で可能になった。

$\mathrm{CNN}$ は損失関数の值が最小になるように, 特徴量 を抽出するパラメー夕を決定するため, 損失関数の選 択は重要である。特に，マスク領域と非マスク領域の 不均衡は損失関数の値に与える影響は大きい ${ }^{45)}$. 本研 究において, 横隔膜付近の脾臓はマスク領域と非マス ク領域の不均衡になる領域であるが過抽出や未抽出は
少なく, 損失関数は適切であると考える.

しかし，正確度の差は最大でグラフト肝が $14 \%$, 脾 臓が $50 \%$ 認められた.グラフト肝と脾臓の境界不明 瞭である被検者に扔いて，グラフト肝は過抽出，脾臓 は過抽出，未抽出ともに増加することで正確度が低下 した(Fig. 10,11)。U-Netは画像フィル夕の盢み込み により特徵量を抽出するため, 境界不明瞭でコントラ ス卜差が少ない被検者は, 画像フィル夕による特徵量 抽出が困難になり正確度が低下した，脾臓の体積はグ ラフト肝と比較して小さく, 過抽出および未抽出体積 が占める割合が高くなり，グラフト肝と比較して正確 度の差が増加したと考える。更に, 脾臓のデータセッ 卜において，境界不明瞭領域の一部に脾臓マスクがあ るため, 自動抽出モデルが境界不明瞭領域の一部のみ を抽出することで未抽出がグラフト肝と比較して増加 したと考える．境界コントラストを強調することで正 確度が改善すると考えるが， CT 画像再構成関数にお ける高周波強調関数，薄いスライス厚使用により，画 像ノイズが増加するため体積測定精度に影響を及ぼ す。画像ノイズ低減を目的として, 逐次近似応用再構 成である SAFIRE 強度の変更, $3 \mathrm{D}$ バイラテラルフィ ル夕 ${ }^{46)}$ の検討が必要である。また，境界が明瞭である 被検者では 90\%以上抽出可能であったが, 微小血管の 過抽出が増加した. U-Netでは解像度 $512 \times 512$ pixels を max poolingにより解像度 $32 \times 32$ pixels までダウン サンプリングされるため微小血管の特徵を捉えるのが 困難であったと考える。

U-Net は 2D スライスを用いて特徵量を抽出するた め, 体軸方向のマスクの連続性は考慮されない.グラ フト肝, 脾臓の抽出結果においても連続性が保たれて いない領域が存在した. 3D U-Netは U-Netの畳み込 み層を三次元に拡張することで体軸方向の特徵量抽出 が可能になり, U-Net と比較して精度が向上する ${ }^{47)}$. しかし，3D U-Netによる学習はGPUメモリ不足によ り困難であった，本研究ではパラメータの検討は行わ れていないが, パラメータの違いは学習時間, 正確度 に影響するため，検討が必要である。

正確度は，3DWS の機能である物体抽出を用いてグ ラフト肝および脾臓マスクを抽出し体積測定した結果 を用いた，教師画像の voxel 值は 1024 に設定したが, 自動抽出画像は U-Net の活性化関数である sigmoid 関数により出力された 0-1に 1024 を乗じたvoxel 值 が 3DWS で表示される. 3DWSの 3D ビューアで物 体抽出する際には閾值の設定が必要になるが, 閾值を 1 以上に設定することで抽出領域が過小評価される. また，一部の 3DWS では，3D ビューアで物体抽出後 


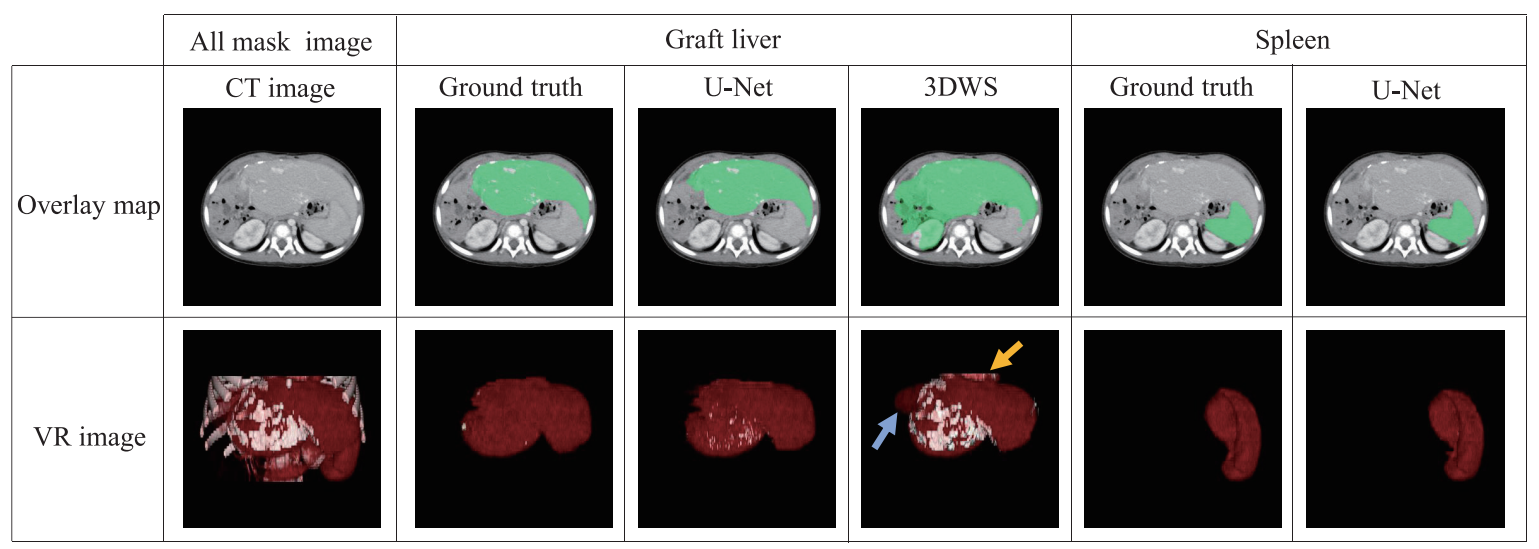

Fig. 9 Comparison of extraction accuracy between 3DWS and U-Net.

Ground truth, U-Net segmentation, and 3DWS liver segmentation application overlay map and VR image. The green area indicates the result of segmentation. The "All mask image" VR image reflects masking of all areas. However, the overlay is not displayed in the CT image. U-Net allows more accurate segmentation than 3DWS. There is no application in 3DWS for the segmentation of the spleen. The white color in the VR image indicates bones and calcification. Dark red indicates the graft liver, spleen, and intestine. Pink color indicates the heart and kidney. The yellow arrow indicates the incorrectly extracted heart. The blue arrow indicates the incorrectly extracted intestine.

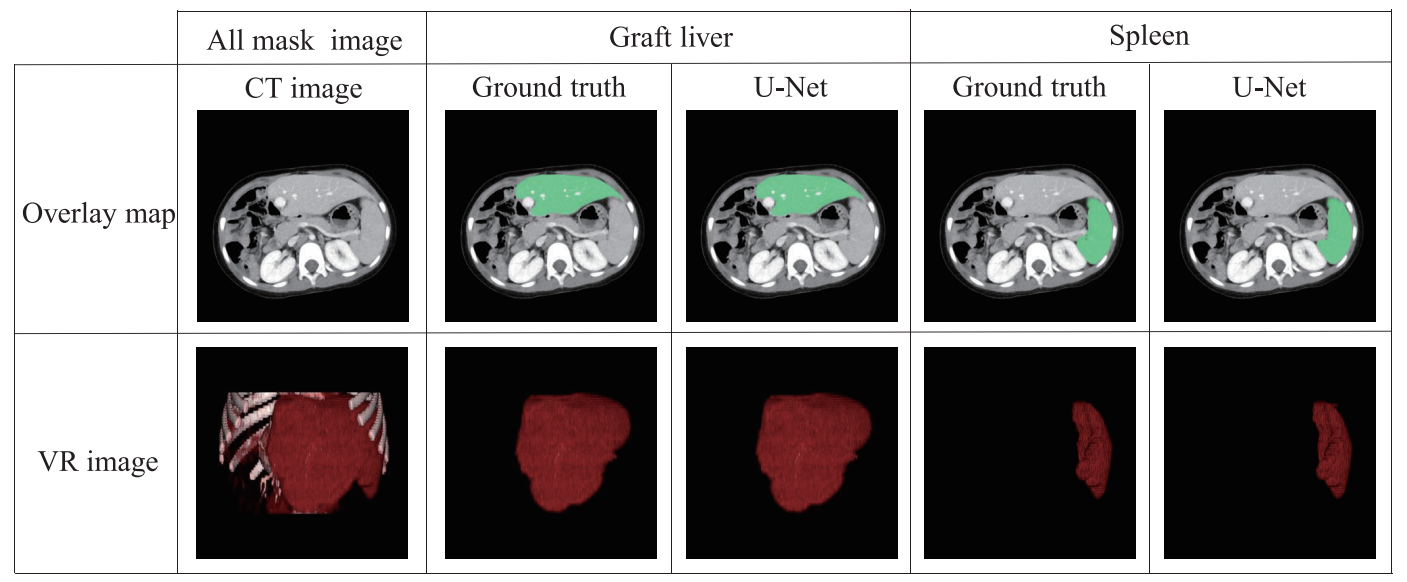

Fig. 10 Example of high-accuracy image.

U-Net segmentation overlay map and VR image. If there is a clear boundary between the graft liver and spleen, then accurate segmentation is possible. The white color in the VR image indicates bones. Dark red indicates the graft liver and spleen. Pink color indicates the heart and kidney.

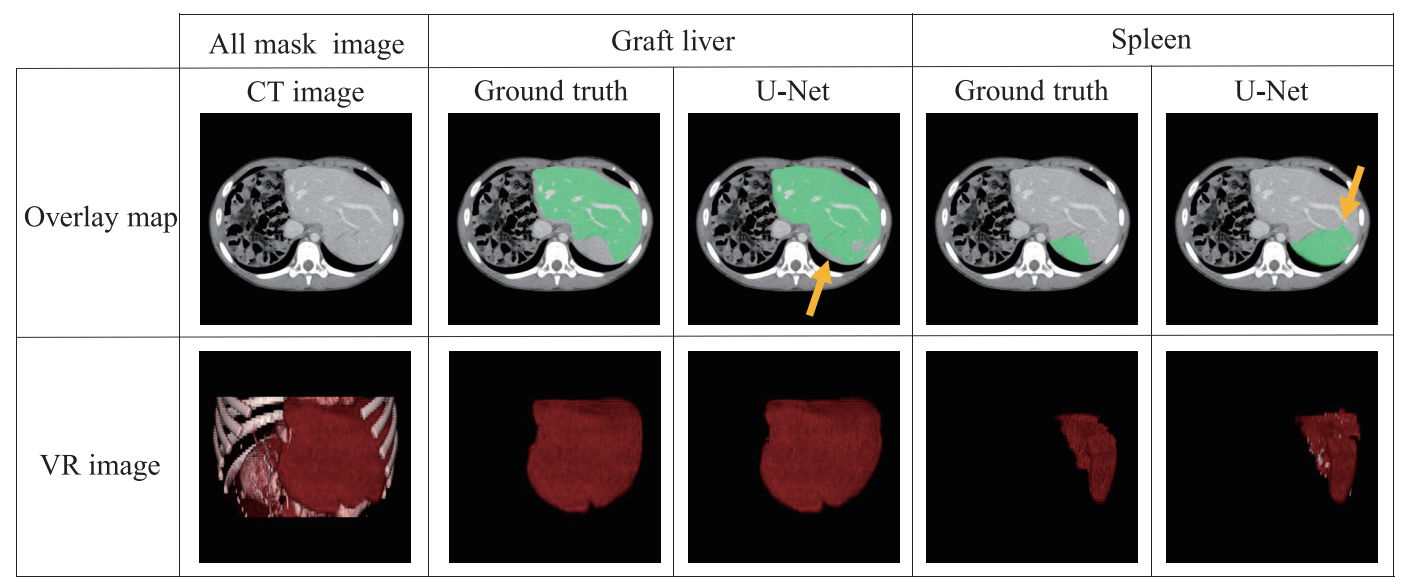

Fig. 11 Example of low-accuracy image.

U-Net segmentation overlay map and VR image. If the boundary between the graft liver and spleen is unclear, then accurate segmentation is difficult. The white color in the VR image indicates bones. Dark red indicates the graft liver and spleen. Pink color indicates the heart and kidney. There is excessive extraction in the area indicated by the yellow arrow. 
のマスク拡張が測定誤差要因になるため, 注意が必要 である。

データセット作成時の手作業による領域抽出は, 被 検者 1 人あたり 30 分程度を要した。しかし，3DWS は ROI 設定時に臓器の輪郭が認識されることで, ROI の設定ポイントが最小限になった。更に ROI はスラ イス方向に補間されるため, ROI 面積の変化が小さい 場合, ROI 設定の省略が可能であり, データセット作 成が簡略化された。個人情報の取り扱い，倫理的配慮 が必要であるが，3DWS はPACS に接続されている 場合が多く，効率的なデータセット作成が可能になる.

作成されたDICOM ファイルは3DWS でインポー 卜，体積測定が可能であった。 CT 画像とのフュー ジョンでは, DICOM tag (0020, 0032)の image position が同一の值であるため, ミスレジストレーション は認められなかった。 また, SOP instance UID, series instance UID を重複しない值に変更することで, 自動抽出画像は CT 画像, 教師画像と異なるシリーズ として認識された。これにより, CT画像と自動抽出 画像のフュージョンが可能になり自動抽出領域の解剖 学的位置が CT 画像上で確認が可能になった。更に, DICOM header を付加することで PACS 送信にも対 応可能になると考える。

本研究のデータセットは, 診療放射線技師一人がグ ラフト肝と脾臓が境界不明瞭である CT 画像から手動 抽出して作成した。診療放射線技師一人のみでは，境 界不明慮であるグラフト肝と脾臓の境界を正確に手動 抽出されていたか不明である。データセットのより高 い精度を担保するために, 放射線科医, 移植外科医が
データセットの正当性を判断することが望まれる。ま た, 3DWSのグラフト肝と脾臓の体積精度を検証する ためには，実際のグラフト肝および脾臓の実測体積と 手動測定体積を比較する必要があると考える。

\section{4. 結 語}

既存の 3DWS では抽出困難である小児生体肝移植 患者のグラフト肝および脾臓の自動抽出をU-Netに て行った結果, どちらも正確に自動抽出することがで きた. 更にU-Netの抽出結果に DICOM header を付 加することで DICOM ファイルを作成し, 3DWS にイ ンポートすることで体積測定, 抽出領域の解剖学的位 置確認, PACS への抽出結果送信が対応可能になっ た。したがって本研究の提案手法により小児生体肝移 植後のグラフト肝, 脾臓体積測定の時間短縮, および 負担軽減を困ることが可能である.

\section{謝 辞}

本研究にご協力いただきました自治医科大学附属病 院のスタッフの皆様に感謝申し上げます。

なお, 本研究の要旨は第 47 回日本放射線技術学会 秋季学術大会 $(2019$ 年, 大阪)にて, 論文投稿を推薦さ れた。

\section{利益相反}

筆頭著者および共著者全員に開示すべき利益相反は ない.

\section{参考文献}

1）肝移植研究会. 肝移植症例登録報告. 肝臓 1998; 39(1): 512.

2）伊藤泰雄 監修. 高松英夫, 福澤正洋, 上野 滋 編. 標準 小児外科学(第 6 版)。東京: 医学書院, 2012 .

3) 日本肝移植学会. 肝移植症例登録報告. 移植 2019; 54(23): 81-96.

4）金澤郁恵, 佐島 毅, 川島 瞳, 他. 小児肝移植後の保育 園・幼稚園および小学校生活の実態. 移植 2017; 52(4-5): 352-359.

5) Urata K, Kawasaki S, Matsunami H, et al. Calculation of child and adult standard liver volume for liver transplantation. Hepatology 1995; 21(5): 1317-1321.

6) Haga J, Shimazu M, Wakabayashi G, et al. Liver regeneration in donors and adult recipients after living donor liver transplantation. Liver Transpl 2008; 14(12): 1718-1724.

7) Chikamori F, Nishida S, Selvaggi G, et al. Effect of liver transplantation on spleen size, collateral veins, and platelet counts. World J Surg 2010; 34(2): 320-326.

8）田中秀明, 菅原寧彦, 幕内雅敏. 肝移植後の経過と予後
4. 術後合併症とその対応. 肝臓 2001; 42(2): 59-62.

9) Kawasaki S, Makuuchi M, Matsunami H, et al. Preoperative measurement of segmental liver volume of donors for living related liver transplantation. Hepatology 1993; 18(5): 11151120.

10) Ohshima S. Volume analyzer SYNAPSE VINCENT for liver analysis. J Hepato-Biliary-Pancreat Sci. 2014; 21: 235-238.

11）周 向栄，藤田広志. ディープラーニングに基づく CT 画像からの複数の解剖学的構造の同時抽出. 医用画像情 報会誌 2017; 34(2): 63-65.

12）森健策。医用画像解析における機械学習の活用。医用 画像情報会誌 2017; 34(2): 66-69.

13) Wang Z, Meng Y, Weng F, et al. An effective CNN method for fully automated segmenting subcutaneous and visceral adipose tissue on CT scans. Ann Biomed Eng 2020; 48(1): 312-328.

14) Baskaran L, Maliakal G, Al'Aref SJ, et al. Identification and quantification of cardiovascular structures from CCTA: an endto-end, rapid, pixel-wise, deep-learning method. JACC: Cardiovascular Imaging 2020; 13(5), 1163-1171. 
15) Daoud B, Morooka K, Kurazume R, et al. 3D segmentation of nasopharyngeal carcinoma from $\mathrm{CT}$ images using cascade deep learning. Comput Med Imaging Graph 2019; 77: 101644.

16) Ronneberger $\mathrm{O}$, Fischer $\mathrm{P}$, Brox $T$, et al. U-net: Convolutional networks for biomedical image segmentation. Medical Image Computing and Computer-Assisted Intervention-MICCAI 2015, 2015; 234-141.

17) Han $X$. Automatic liver lesion segmentation using a deep convolutional neural network method. arXiv preprint arXiv; 1704.07239 .

18) Moon H, Huo Y, Abramson RG, et al. Acceleration of spleen segmentation with end-to-end deep learning method and automated pipeline. Comput Biol Med 2019; 107: 109-117.

19) Norman B, Pedoia V, Majumdar S. Use of 2D U-Net convolutional neural networks for automated cartilage and meniscus segmentation of knee MR imaging data to determine relaxometry and morphometry. Radiology 2018; 288(1): 177185.

20）神谷直希, 家田皓将, 周 向栄, 他. X 線 CT 画像におけ るアトラス構築に基づく胸鎖乳突筋自動認識の初期検討. 医用画像情報会誌 2017; 34(2): 87-91.

21) Im KC, Choi IS, Ryu JS, et al. PET/CT fusion viewing software for use with picture archiving and communication systems. J Digit Imaging 2010; 23(6): 732-743.

22) Kolařík M, Burget R, Uher V, et al. Optimized high resolution 3D Dense-U-Net network for brain and spine segmentation. Appl Sci 2019; 9(3): 404.

23) Nemoto T, Futakami N, Yagi M, et al. Efficacy evaluation of 2D, 3D U-Net semantic segmentation and atlas-based segmentation of normal lungs excluding the trachea and main bronchi. J Radiat Res 2020; 61(2): 257-264.

24) Dabiri S, Popuri K, Cespedes Feliciano EM, et al. Muscle segmentation in axial computed tomography (CT) images at the lumbar (L3) and thoracic (T4) levels for body composition analysis. Comput Med Imaging Graph 2019; 75: 47-55.

25）最新の国内実態調査結果に基づく診断参考レベルの設定. http://www.radher.jp/J-RIME/report/DRLhoukokusyo.pdf (Accessed 2019.11.21)

26) Han BK, Grant KL, Garberich R, et al. Assessment of an iterative reconstruction algorithm (SAFIRE) on image quality in pediatric cardiac CT datasets. J Cardiovasc Comput Tomogr 2012; 6(3): 200-204.

27) Baumueller S, Winklehner A, Karlo C, et al. Low-dose CT of the lung: potential value of iterative reconstructions. Eur Radiol 2012; 22(12): 2597-2606.

28) von Falck $C$, Bratanova $V$, Rodt $T$, et al. Influence of sinogram affirmed iterative reconstruction of $\mathrm{CT}$ data on image noise characteristics and low-contrast detectability: an objective approach. PLoS ONE 2013; 8(2): e56875.

29) Hardie AD, Nelson RM, Egbert R, et al. What is the preferred strength setting of the sinogram-affirmed iterative reconstruction algorithm in abdominal CT imaging? Radiol Phys Technol 2015; 8(1): 60-63.

30）原武史, 松原友子, 李 鎔範. データの準備/前処理. 2.2.2 画像ファイルの読み込み。標準医用画像のための ディープラーニング一実践編一. 藤田広志 監修. 東京 : オーム社, 2019: 34.
31）原武史, 松原友子, 李 鎔範. 画像の領域分割 (U-Net). 5.3 U-Net の構造. 標準 医用画像のためのディープラー ニング一実践編一. 藤田広志 監修. 東京 : オーム社, 2019: 83.

32) Agarap AF. Deep learning using rectified linear units (ReLu). arXiv preprint arXiv 2018; 1803.08375.

33）原 武史, 松原友子, 李 鎔範. 評価方法. 11.3.2 画像領 域の評価の実践. 標準 医用画像のためのディープラーニ ング一実践編一. 藤田広志 監修. 東京 : オーム社, 2019: 194.

34) Bertels J, Robben D, Vandermeulen D, et al. Optimization with soft Dice can lead to a volumetric bias. arXiv preprint arXiv 2019; 1911.02278.

35) Tang P, Liang Q, Yan X, et al. Efficient skin lesion segmentation using separable-Unet with stochastic weight averaging. Comput Methods Programs Biomed 2019; 178: 289301.

36) Antonio Gulli, Sujit Pal. 大串正矢, 久保隆宏, 中山光樹 訳. 直感 Deep Learning 一Python $\times$ Keras でアイデアを形にする レシピ. 東京：オーム社, 2018.

37) Keskar NS, Mudigere D, Nocedal J, et al. On large-batch training for deep learning: generalization gap and sharp minima. arXiv preprint arXiv. 2017; 1609.04836.

38) Oktay O, Schlemper J, Folgoc L, et al. Attention u-net: learning where to look for the pancreas. arXiv preprint arXiv 2018; 1804.03999 .

39) Gupta D, Kim M, Vineberg K, et al. Generation of synthetic CT images from MRI for treatment planning and patient positioning using a 3-channel U-Net trained on sagittal images. Front Oncol 2019; 25(9): 964.

40) Ma X, Hadjiiski LM, Wei J, et al. U-Net based deep learning bladder segmentation in CT urography. Med Phys 2019; 46(4): 1752-1765.

41) Kingma DP, Ba J. Adam: a method for stochastic optimization. arXiv preprint arXiv 2014; 1412.6980 .

42) Sebastian Raschka. 福島真太朗 訳. Python 機械学習プロ グラミング 達人データサイエンティストによる理論と実 践. 東京：オーム社, 2016 .

43) Gibson E, Giganti F, Hu Y, et al. Automatic Multi-Organ Segmentation on Abdominal CT with Dense V-networks. IEEE Trans Med Imaging 2018; 37(8): 1822-1834.

44) Li X, Chen H, Qi X, et al. H-DenseUNet: hybrid densely connected UNet for liver and tumor segmentation from CT volumes. IEEE Trans Med Imaging 2018; 37(12): 2663-2674.

45) Carole H, Wenqi L, Vercauteren $T$, et al. Generalised Dice overlap as a deep learning loss function for highly unbalanced segmentations. Deep Learning in Medical Image Analysis and Multimodal Learning for Clinical Decision Support. Springer, 2017; 240-248.

46) Ichikawa K, Kawashima H, Shimada $M$, et al. A threedimensional cross-directional bilateral filter for edgepreserving noise reduction of low-dose computed tomography images. Comput Biol Med 2019; 111: 103353.

47) Çiçek Ö, Abdulkadir A, Lienkamp S, et al. 3D U-NET: Learning dense volumetric segmentation from sparse annotation. arXiv preprint arXiv 2016; 1606.06650 . 